\title{
Synthesis of star-like $\mathrm{MnO}_{2}-\mathrm{CeO}_{2} / \mathrm{CNT}$ composite as an efficient cathode catalyst applied in lithium-oxygen batteries
}

\author{
Masoumeh Salehi, Zahra Shariatinia*
}


A $\mathrm{MnO}_{2}-\mathrm{CeO}_{2} / \mathrm{CNT}$ nanostructure is synthesized using hydrothermal method for which the amounts of CNT, $\mathrm{CeO}_{2}$ and $\mathrm{MnO}_{2}$ are determined using TGA and ICP-OES analysis equal to 55\%, $25 \%$ and $20 \%$, respectively. The $\mathrm{MnO}_{2}-\mathrm{CeO}_{2} / \mathrm{CNT}$ nanocomposite is characterized using SEM, EDS-SEM, XRD, BET, TGA and ICP techniques and used as an efficient cathodic electrocatalyst in the lithium-oxygen battery. The energy storage capacity of the lithium-oxygen battery fabricated using pristine CNT is about $4100 \mathrm{~mA} \cdot \mathrm{h} / \mathrm{g}_{\text {electrode }}$ at $100 \mathrm{~mA} / \mathrm{g}_{\text {electrode }}$ current density but that of $\mathrm{MnO}_{2}-\mathrm{CeO}_{2} / \mathrm{CNT}$ nanocatalyst is $7980 \mathrm{~mA} . \mathrm{h} / \mathrm{g}_{\text {electrode }}$ at the $50 \mathrm{~mA} / \mathrm{g}_{\text {electrode }}$ current density and 6860 $\mathrm{mA} \cdot \mathrm{h} / \mathrm{g}_{\text {electrode }}$ at the $100 \mathrm{~mA} / \mathrm{g}_{\text {electrode }}$ current density showing a $68 \%$ improvement in the battery performance. The charge and discharge over-voltages are 0.68 and $0.20 \mathrm{~V}$, respectively, for $\mathrm{MnO}_{2}$ $\mathrm{CeO}_{2} / \mathrm{CNT}$ while they are 1.44 and $0.32 \mathrm{~V}$ for $\mathrm{CNT}$, respectively, at the $100 \mathrm{~mA} / \mathrm{g}_{\text {electrode }}$ current density exhibiting $52 \%$ and $37.5 \%$ decrease in charge and discharge over-voltages. The cyclic performance of the $\mathrm{MnO}_{2}-\mathrm{CeO}_{2} / \mathrm{CNT}$ nanostructure cathode is considered at 70 cycles reflecting its appropriate performance. The electrochemical impedance spectroscopy (EIS) illustrates a suitable reversibility for the synthesized cathode in such a way that the resistance created at discharge is diminished at the charging process.

Keywords: Lithium-oxygen battery; Electrochemical impedance spectroscopy (EIS); Nanocomposite; Cycleability; Reversibility 


\section{Introduction}

Using portable energy storage devices has been increased in cellphones, laptops, cameras and so on during recent years. The growing demand has been concentrated on using electrochemical systems having high energy density, high power density and appropriate lifetime such as batteries, fuel cells, and pseudo-fuel cells [1-3]. Lithium-air batteries have the highest energy storage capacity among other batteries and semi-fuel cells [4-8]. However, one should overcome many challenges including high over-voltage, low cycleability, and electrolyte instability in order to be able to present such batteries for application [9-10].

The cathode is of critical importance in lithium-air batteries since the oxygen reduction reaction $(\mathrm{ORR})$ and oxygen evolution reaction $(\mathrm{OER})$ occur at the cathode but their low reaction kinetics results in over-voltage and inappropriate cycleability [11-12]. Regarding the low kinetics of these reactions, a high deviation is also observed between charge and discharge potentials in the battery. Catalysts can have a critical role in decreasing the over-potential during charge and discharge processes through facilitating the OER and ORR reactions which leads in increasing the battery performance [10,13-17]. Catalysts used in the lithium-air batteries are categorized to four classes including metals (noble and non-noble) [15,18], carbonaceous materials [23-24] and composite compounds.

Composites are materials which have shown noticeable performances in the lithium-air batteries $[17,25]$. They can be formed from a carbonaceous support and one or a couple of metal catalysts or metal oxides having two positive effects on the battery performance as follows: (i) they have high capacities to store precipitations within the porous and spacious carbon structure, (ii) metals and metal oxides can have catalytic influences in accompany with the carbonaceous structure [26]. 
Ping et al. [27] applied a mesoporous TiC-C composite as the catalyst in the lithium-air battery and obtained $3500 \mathrm{~mA} . \mathrm{h} / \mathrm{g}$ capacity at the $100 \mathrm{~mA} / \mathrm{g}$ current density. The mentioned catalyst showed an appropriate cycleability during 80 cycles having a limited capacity of $500 \mathrm{~mA} \cdot \mathrm{h} / \mathrm{g}$ at 100 $\mathrm{mA} / \mathrm{g}$ current density.

Dangsheng et al. [28] used the onion-like carbon doped with nitrogen in the lithium-air battery and found a noticeable capacity of $12500 \mathrm{~mA} \cdot \mathrm{h} / \mathrm{g}$ at the $0.15 \mathrm{~mA} / \mathrm{cm}^{2}$ current density while $9400 \mathrm{~mA} . \mathrm{h} / \mathrm{g}$ capacity at $0.6 \mathrm{~mA} / \mathrm{cm}^{2}$ current density. Jian et al. utilized a core-shell $\mathrm{RuO}_{2} / \mathrm{CNT}$ structure in the lithium-air battery and achieved $4350 \mathrm{~mA} . \mathrm{h} / \mathrm{g}$ capacity but a discharge capacity of only $3258 \mathrm{~mA} . \mathrm{h} / \mathrm{g}$ [29]. Liu et al. synthesized cublic and octahedral $\mathrm{Co}_{3} \mathrm{O}_{4}$ structures which produced capacities equal to 2463 and $1787 \mathrm{~mA} . \mathrm{h} / \mathrm{g}$, respectively, at $100 \mathrm{~mA} / \mathrm{g}$ current density [30]. Shen et al. [31] electrochemically synthesized Pd on spongy CNT which resulted in $9092 \mathrm{~mA} . \mathrm{h} / \mathrm{g}$ capacity with $2.65 \mathrm{~V}$ at $0.05 \mathrm{~mA} / \mathrm{cm}^{2}$ current density. Using composites improved the cathode performance through protecting carbon against direct contact with discharge precipitates as well as increasing the conductivity and homogenous dispersion of catalyst.

$\mathrm{CeO}_{2}$ catalyst has spawned a considerable interest because of its high oxygen ion conductivity and good mechanical resistance in fuel cells [32]. Also, it acts as an oxygen buffer to compensate the oxygen deficiency [33]. Jian et al. [33] synthesized $\mathrm{CeO}_{2}$ nanorods covered with $\mathrm{MnO}_{\mathrm{x}}$ which showed a high performance as the battery cathode with $2617 \mathrm{~mA} . \mathrm{h} / \mathrm{g}$ capacity at $100 \mathrm{~mA} / \mathrm{g}$ current density. Chung et al. [34] synthesized $\mathrm{CeO}_{2} / \mathrm{Ag}$ core-shell nanocomposite that illustrated 3415 $\mathrm{mA} . \mathrm{h} / \mathrm{g}$ capacity at $100 \mathrm{~mA} / \mathrm{g}$ current density indicating improved battery efficiency compared with $\mathrm{CeO}_{2}$ and $\mathrm{CeO}_{2}-\mathrm{Ag}$. These studies confirm that using cerium oxide mixed with other catalysts increases the cathode performance. 
In this work, $\mathrm{MnO}_{2}-\mathrm{CeO}_{2} / \mathrm{CNT}$ nanocomposite was synthesized by hydrothermal method. This composite was analyzed using XRD, FE-SEM, TGA, and BET analyses. The obtained surface area of this composite was $93 \mathrm{~m}^{2} / \mathrm{g}$ which was $10 \%$ lower than that of the CNT while it was $15 \%$ higher compared to that of $\mathrm{CNT} / \mathrm{MnO}_{2}$. The electrochemical performance of the nanocomposite was evaluated by its application as the cathode catalyst in lithium-oxygen batteries. The $\mathrm{MnO}_{2^{-}}$ $\mathrm{CeO}_{2} / \mathrm{CNT}$ composite showed 6860 and $7980 \mathrm{~mA} . \mathrm{h} / \mathrm{g}_{\text {electrode }}$ capacities at 100 and $50 \mathrm{~mA} / \mathrm{g}_{\text {electrode }}$ current densities, respectively. The charge and discharge over-voltages of this composite at 100 $\mathrm{mA} / \mathrm{g}_{\text {electrode }}$ urrent density were measured equal to 0.68 and $0.2 \mathrm{~V}$, respectively,

\section{Experimental section}

\subsection{Synthesis of $\mathrm{MnO}_{2}-\mathrm{CeO}_{2} / \mathrm{CNT}$ nanocomposite}

MWCNT was purchased from Research Institute of Petroleum Industry (90\% purity and particle size of $10-15 \mathrm{~nm}) . \mathrm{KMnO}_{4}$ and urea were purchased from Merck Company but $\mathrm{Ce}\left(\mathrm{NO}_{3}\right)_{3} \cdot 6 \mathrm{H}_{2} \mathrm{O}$ and $\mathrm{CO}\left(\mathrm{NH}_{2}\right)_{2}$ were obtained from Sigma-Aldrich Company which were used without further purification. Double distilled water was utilized in all experiments. Hydrothermal synthesis was applied to prepare $\mathrm{MnO}_{2}-\mathrm{CeO}_{2} / \mathrm{CNT}$ nanocomposite. To do this, $0.05 \mathrm{~g} \mathrm{CNT}$ was dispersed during $10 \mathrm{~min}$ in $50 \mathrm{~mL}$ double distilled water using ultrasonic probe. Then, $0.0253 \mathrm{~g}$ of cerium nitrate hexahydrate and $0.22 \mathrm{~g}$ urea were added to the CNT suspension and the mixture was stirred for 10 minutes. Next, $0.0182 \mathrm{~g}$ of $\mathrm{KMnO}_{4}$ was added and the reaction content was moved to a Teflon-lined stainless steel autoclave which was heated at $160{ }^{\circ} \mathrm{C}$ for $24 \mathrm{~h}$. Finally, the obtained mixture was cooled at room temperature and washed with distilled water after filtration. The product was dried at $80{ }^{\circ} \mathrm{C}$ for $24 \mathrm{~h}$. The synthesis of optimized CNT-60\% $\mathrm{MnO}_{2}$ was performed according to reference [17]. 


\subsection{Characterization of nanocomposite}

The morphology and structure of the nanocomposite was studied using VEGA series of Scanning Electron Microscopy (SEM) and Energy dispersive analysis of X-rays (EDS) analysis. The X-ray diffraction (XRD) patterns were obtained using Philips X'Pert X-ray diffractometer. The thermal gravimetric analysis (TGA) was performed on a PL-TGA system. The nitrogen adsorption and desorption measurements were done using PMI Sorptometer analyzer at $77 \mathrm{~K}$ and the specific surface areas were evaluated through the Brunauer-Emmett-Teller (BET) isotherms. Prior to the physisorption measurements, the samples were degassed at $200{ }^{\circ} \mathrm{C}$ under the $\mathrm{N}_{2}$ flow for $3 \mathrm{~h}$. The ICP-OES model Varian Vista-PRO (nebulizer V-groove) with a Charge coupling detector (CCD) was used for elemental analysis of $\mathrm{Mn}$ and $\mathrm{Ce}$ in the produced nanocomposite.

\subsection{Electrochemical analysis}

The oxygen cathode was prepared by spraying a suspension containing materials on carbon paper (TGP-H 060 toray) of about $1 \pm 0.1 \mathrm{mg} / \mathrm{cm}^{2}$. The suspension was obtained by sonication of $85 \%$ $\mathrm{MnO}_{2}-\mathrm{CeO}_{2} / \mathrm{CNT}$ and $15 \%$ PTFE in isopropanol/water solution with a 3:1 v/v ratio. The cathode was dried at $80{ }^{\circ} \mathrm{C}$ for 12 hours and transformed into an argon filled glove box. All needed materials for battery were kept in the glove box. The battery was assembled in the glove box as well. A lithium foil ( $0.5 \mathrm{~mm}$ thick) was used as an anode and a glass fiber filter (Whatman GF/F) was applied as a separator. Also, a $0.5 \mathrm{M}$ solution of $\mathrm{LiClO}_{4}$ in DMSO/dimethylacetamide (1:1 v/v) was employed as an electrolyte. The battery was assembled in a coin cell form having a surface area of $3.14 \mathrm{~cm}^{2}$ and kept under the $2 \mathrm{~atm}$ pressure of pure oxygen (99.9\%) during the electrochemical analyses. Discharge-charge analyses were performed at the potential range of $2.0-4.5 \mathrm{~V}$ in a constant current condition using the battery analyzer Kimiastat 125 (Iran). The specific capacity 
was calculated based on the total weight of cathode electrode $\left(\mathrm{mA} \cdot \mathrm{h} / \mathrm{g}_{\text {electrode }}\right)$ and the current density was expressed based on the total weight of electrode $\left(\mathrm{mA} / \mathrm{g}_{\text {electrode }}\right)$. The EIS analyses were carried out using the potentiostat/galvanostat PARSTAT 2273 (Princeton Applied Research) at Open Circuit Potential (OCP), $10 \mathrm{mV}$ amplitude and $100 \mathrm{mHz}-10 \mathrm{MHz}$ frequency range.

\section{Results and discussion}

\subsection{Characterization of $\mathrm{MnO}_{2}-\mathrm{CeO}_{2} / \mathrm{CNT}$ nanocomposite}

The XRD pattern of $\mathrm{MnO}_{2}-\mathrm{CeO}_{2} / \mathrm{CNT}$ composite along with those of $\mathrm{CeO}_{2}$ and $\mathrm{MnO}_{2}$ are shown in Fig. S1 indicating the $\mathrm{MnO}_{2}$ diffraction peaks at $2 \theta=12.8,18.2,25.8,28.9,36.8,37.6,41.3,42.0$, 49.8, 56.4, 60.3 and $69.7^{\circ}$ are sharp and intense which confirms that $\mathrm{MnO}_{2}$ crystal structure is the typical $\alpha-\mathrm{MnO}_{2}$ with good crystalline structure based on the standard JCPDS card No. 44-0141. The XRD pattern of $\mathrm{CeO}_{2}$ is according to JCPDS 81-0792 which shows fluorite structure of $\mathrm{CeO}_{2}$.

The SEM image of $\mathrm{MnO}_{2}-\mathrm{CeO}_{2} / \mathrm{CNT}$ nanocomposite is presented in Fig. 1a for which starlike nanostructures are observed among CNTs. In fact, the repeated homogeneous star-like units are obvious during all structure. The EDS spectrum of $\mathrm{MnO}_{2}-\mathrm{CeO}_{2} / \mathrm{CNT}$ nanocomposite is given in Fig. 1b. This analysis verifies the presence of $\mathrm{C}, \mathrm{Mn}, \mathrm{Ce}$ and $\mathrm{O}$ elements in the $\mathrm{MnO}_{2}-\mathrm{CeO}_{2} / \mathrm{CNT}$ material. Other peaks are attributed to impurities and also the gold layer coated on the sample. Also, the mapping of $\mathrm{MnO}_{2}-\mathrm{CeO}_{2} / \mathrm{CNT}$ composite in Fig. 1c illustrates the homogenous distributions of CNT, $\mathrm{CeO}_{2}$ and $\mathrm{MnO}_{2}$ throughout the composite.

In order to estimate the exact $\mathrm{MnO}_{2}-\mathrm{CeO}_{2}$ content in the $\mathrm{MnO}_{2}-\mathrm{CeO}_{2} / \mathrm{CNT}$ nanocomposite, the TGA analysis was performed and its diagram is revealed in Fig. S2a in which the weight loss of $3 \%$ below $250{ }^{\circ} \mathrm{C}$ is related to the evaporation of interlayer water molecules. The total weight loss of $55 \%$ at about $430{ }^{\circ} \mathrm{C}$ is due to the combustion of CNT in air. Thus, it can be estimated that the 
amount of $\mathrm{MnO}_{2}-\mathrm{CeO}_{2}$ in the composite is $\approx 45 \%$. The ICP-OES results confirm that the nanocomposite is comprised of 20 and $25 \%$ (w/w) of $\mathrm{MnO}_{2}$ and $\mathrm{CeO}_{2}$, respectively.

The specific surface area was measured using the nitrogen adsorption/desorption analysis. Fig. S2b demonstrates the physisorption isotherms for the CNT, optimized CNT-60\% $\mathrm{MnO}_{2}$ [17] and $\mathrm{MnO}_{2}-\mathrm{CeO}_{2} / \mathrm{CNT}$ nanocomposite. The specific surface areas measured from BrunauerEmmett-Teller (BET) isotherms and also the average pore volumes are summarized at Table 1. According to Fig. S2b and Table 1, the specific surface area and the average pore volume for $\mathrm{MnO}_{2}-\mathrm{CeO}_{2} / \mathrm{CNT}$ are lower compared to those of $\mathrm{CNT}$ while they are higher than those of optimized CNT-60\% $\mathrm{MnO}_{2}$ [17]. The reason for greater specific surface area and the average pore volume for $\mathrm{MnO}_{2}-\mathrm{CeO}_{2} / \mathrm{CNT}$ compared with those of $\mathrm{CNT}-60 \% \mathrm{MnO}_{2}$ may be related to the lower total metal oxides amount $(\approx 45 \%)$ used in the synthesis of $\mathrm{MnO}_{2}-\mathrm{CeO}_{2} / \mathrm{CNT}$ leading to lower filling of CNT surface/pores.

\subsection{Electrochemical performance of $\mathrm{MnO}_{2}-\mathrm{CeO}_{2} / \mathrm{CNT}$ nanocomposite}

Since it is known that heat treatment increases the catalytic and chemical stability, removes impurities and increases the porosity of the cathode material [16], the heat treatment was applied for our cathodes. The fabricated cathodes using $\mathrm{MnO}_{2}-\mathrm{CeO}_{2} / \mathrm{CNT}$ and $\mathrm{CNT}$ materials were heat treated at 280 and $350{ }^{\circ} \mathrm{C}$ for 30 min after drying. The cathode samples were produced without and with heat treatment to compare the effect of heat treatment on their performances. The reason for employing heat treatment can be described as heat treatment can remove problematic water content exists as surface water and protons associated with vacancy and $\mathrm{Mn}(\mathrm{III})$ structural defects [35]. The effect of heat treatment on the structure of electrolytic manganese dioxide (EMD), which is prepared by electrolysis, has been well documented in literature [35]. Indeed, upon heating, the 
EMD $\left(\gamma-\mathrm{MnO}_{2}\right)$ is converted to $\beta-\mathrm{MnO}_{2}$ which is known as a $\gamma / \beta-\mathrm{MnO}_{2}$ phase [35]. Also, it is indicated that heat treatment can result in removal of the problematic water content, exist as surface water and protons associated with vacancy and $\mathrm{Mn}$ (III) structural defects [35]. Lee et al. [36,37] identified three types of water in EMD using temperature programmed desorption (TPD): Type 1 water, which is physisorbed water which can be reversibly removed around $100{ }^{\circ} \mathrm{C}$; Type 2 water, which is composed of surface bound hydroxyls and water of crystallization that is irreversibly removed around $200{ }^{\circ} \mathrm{C}$; and Type 3 water, which are bulk hydroxyl groups removed irreversibly at $300{ }^{\circ} \mathrm{C}$. Therefore, heat treatment of $\mathrm{MnO}_{2}$ for application in lithium batteries is usually carried out between $250{ }^{\circ} \mathrm{C}$ and $400{ }^{\circ} \mathrm{C}$. Moreover, it is notable that the cathode catalyst retains its crystal structure after heat treatment in this temperature range and becomes more stable [38] providing higher battery performance [16,39]. Additionally, annealing of binder upon heat treatment causes more stiffness and mechanical stability of the catalyst. Considering these beneficial factors for heat treatment, we employed heat treatment on our $\mathrm{MnO}_{2}-\mathrm{CeO}_{2} / \mathrm{CNT}$ catalyst in order to increase the battery capacity.

Fig. 2a illustrates the charge-discharge of lithium-oxygen battery cathodes produced with and without heat treatment. As can be seen, the discharge potential of cathode made using $\mathrm{MnO}_{2}-$ $\mathrm{CeO}_{2} / \mathrm{CNT}$ under heat treatment is $0.25 \mathrm{~V}$ higher than that of the system fabricated without heat treatment. Also, the charge potential of the system made using heat treatment is lower than that of the cathode without heat treatment which is attributed to the impurities removal at $280{ }^{\circ} \mathrm{C}$ and annealing of Teflon binder at $350{ }^{\circ} \mathrm{C}$. The reduction of over-potential resulted from the removal of impurities is because of the fact that it provides an extra space to intercalate the deposits and substrate to pass the oxygen molecules. Moreover, annealing the binder results in binding of catalyst particles to the carbon paper with appropriate electrical conduction. The charge potential in 
the samples obtained with heat treatment is decreased by $0.20 \mathrm{~V}$ compared to those of the samples fabricated without heat treatment. The Nyquist diagrams are shown in Fig. $2 b$ for all 4 cathode samples. It is obvious that the heat treatment reduces the resistance in cathodes by $35 \%$. The results reflect that heat treatment improves the cathode battery performance. Thus, all cathode samples used in our further studies were fabricated using the heat treatment process.

\subsubsection{Determination of over-potentials}

The synthesized $\mathrm{MnO}_{2}-\mathrm{CeO}_{2} / \mathrm{CNT}$ nanocomposite was considered as the cathode catalyst in lithium-oxygen batteries. Firstly, it was discharged under 2 atmospheres of pure oxygen and 100 $\mathrm{mA} / \mathrm{g}_{\text {electrode }}$ current density in order to determine the charge and discharge over-potentials. The CNT and CNT- $\mathrm{MnO}_{2}$ were charged and discharged under the same conditions. The results are summarized at Fig. 3a. As can be seen, the over-voltages of discharge for $\mathrm{MnO}_{2}-\mathrm{CeO}_{2} / \mathrm{CNT}$ and $\mathrm{CNT}-\mathrm{MnO}_{2}$ are the same which are about $0.2 \mathrm{~V}$ while the over-voltage value is 0.32 for pristine CNT which shows a $37.5 \%$ increase when it is used as the cathode catalyst in the battery. The overvoltage for $\mathrm{MnO}_{2}-\mathrm{CeO}_{2} / \mathrm{CNT}$ is about $0.68 \mathrm{~V}$ which exhibits $22 \%$ and $52 \%$ decrease compared to those of CNT- $\mathrm{MnO}_{2}(0.87 \mathrm{~V})$ and CNT $(1.44 \mathrm{~V})$. The Round-trip efficiency of assembled battery using $\mathrm{MnO}_{2}-\mathrm{CeO}_{2} / \mathrm{CNT}$ is $76 \%$ which is higher than that of batteries made by $\mathrm{CNT}-\mathrm{MnO}_{2}(72 \% \mathrm{~V})$ and CNT (61\%). The discharge capacities of the three cathode samples and over-voltages are summarized in Fig. 3b. Increasing the performance of $\mathrm{MnO}_{2}-\mathrm{CeO}_{2} / \mathrm{CNT}$ can be related to the high capability of cerium oxide to conduct the oxygen ion and also storage of oxygen which prevents the oxygen deficiency in the oxygen reduction reaction (ORR) [33].

The reason for decreasing the charge potential using $\mathrm{CeO}_{2}$ in the $\mathrm{MnO}_{2}-\mathrm{CeO}_{2} / \mathrm{CNT}$ catalyst can be attributed to its well-known oxygen storage and release property because (as you mentioned) 
it has intrinsically a very low 'electrical' conductivity. In fact, $\mathrm{CeO}_{2}$ decreases polarization due to its easy shift between reduced and oxidized states (equation 1), which enables it to play as an "oxygen buffer". Therefore, it can provide oxygen under lean conditions and removes it under rich conditions. Also, $\mathrm{CeO}_{2}$ can retain its face cubic structure even when it has a severe deviation from its stoichiometry and the oxygen vacancy creates more sites for its catalytic activity.

$$
\mathrm{CeO}_{2} \leftrightarrow \mathrm{CeO}_{2-\mathrm{x}}+(\mathrm{x} / 2) \mathrm{O}_{2} \quad(0 \leq \mathrm{x} \leq 0.5)
$$

In discharge, the superoxide species $\left(\mathrm{O}_{2}^{-}\right)$are mainly generated on $\mathrm{Ce}^{4+}$ while the peroxide species $\left(\mathrm{O}_{2}{ }^{2-}\right)$ are formed on a pair of surface cerium ions with lower oxidation state. Both of superoxide and peroxide species are involved in the oxygen reduction reaction (ORR) process (equations 2-4). Since $\mathrm{CeO}_{2}$ can rapidly release and uptake oxygen, it could provide relatively sufficient oxygen when discharging leading to less polarization and higher capacity. Moreover, in the charge process, it can act readily as an oxygen adsorbent and facilitates the decomposition of lithium peroxide precipitate resulting in a decrease in charge potential [40].

$$
\begin{aligned}
& \mathrm{nCeO}_{\mathrm{x}}(\mathrm{x}<2, \mathrm{n}>1)+\mathrm{O}_{2} \rightarrow\left[\mathrm{nCeO}_{\mathrm{x}}\right]^{+} \mathrm{O}_{2}{ }^{-} \rightarrow[\mathrm{nCeOx}]^{2+} \mathrm{O}_{2}{ }^{2-} \\
& \mathrm{Li}^{+}+\mathrm{O}_{2}^{-} \rightarrow 2 \mathrm{LiO}_{2} \\
& 2 \mathrm{Li}^{+}+\mathrm{O}_{2}{ }^{2-} \rightarrow \mathrm{Li}_{2} \mathrm{O}_{2}
\end{aligned}
$$

\subsubsection{Discharge capacity at different current densities}

The cathode fabricated using $\mathrm{MnO}_{2}-\mathrm{CeO}_{2} / \mathrm{CNT}$ was discharged under different current densities. Fig. 4 displays the discharge diagrams at current densities from 50 to $3000 \mathrm{~mA} / \mathrm{g}_{\text {electrode. }}$ Evidently, the discharge capacity is decreased at higher current density which is due to low kinetics of oxygen reduction reaction in non-aqueous medium. Table 2 shows the value of discharge capacities at different current densities so that the highest discharge capacity and discharge potential are 
observed at $50 \mathrm{~mA} / \mathrm{g}_{\text {electrode }}$ current density while the $5400 \mathrm{~mA} \cdot \mathrm{h} / \mathrm{g}_{\text {electrode }}$ discharge capacity was obtained at $1000 \mathrm{~mA} / \mathrm{g}_{\text {electrode }}$ current density. The storage capacities are $50 \%$ and $42 \%$ compared with the initial values at 2000 and $3000 \mathrm{~mA} / \mathrm{g}$ current densities, respectively.

\subsubsection{Cycleability}

The cycleability of $\mathrm{MnO}_{2}-\mathrm{CeO}_{2} / \mathrm{CNT}$ nanocomposite was studied as the cathode catalyst in lithiumoxygen battery. Fig. 5a shows the cycleability of $\mathrm{MnO}_{2}-\mathrm{CeO}_{2} / \mathrm{CNT}$ composite at $500 \mathrm{~mA} / \mathrm{g}$ with a limited capacity of $1000 \mathrm{~mA} . \mathrm{h} / \mathrm{g}_{\text {electrode }}$ during 70 cycles. Fig. $5 \mathrm{~b}$ illustrates the variation of oxygen reduction and oxygen evolution potentials at the reaction halfway. As can be seen, no significant drop is observed in capacity after 70 cycles. The potential variations reveal no noticeable voltage change which indicates an appropriate performance of synthesized catalyst in the oxygen reduction process. In contrast, the over-potential of oxygen evolution reaction (OER) is gradually increased which can be attributed to following reasons: (i) the volume change of cathode results in destruction of cathode during charge and discharge cycles which leads in its low conductivity, (ii) formation of unwanted materials such as $\mathrm{Li}_{2} \mathrm{CO}_{3}$ on electrode may block active sites and close the oxygen and lithium ion channels.

Fig. 6a indicates the cyclic performance of the synthesized nanocomposite at $100 \mathrm{~mA} / \mathrm{g}_{\text {electrode }}$ current density and a limited capacity of $500 \mathrm{~mA} \cdot \mathrm{h} / \mathrm{g}_{\text {electrode }}$ Fig. $6 \mathrm{~b}$ shows the potential variations of oxygen reduction and evolution at the reaction halfway. Obviously, the discharge potential has no considerable change during 60 cycles. Also, the charging potential has no significant variation during initial cycles while it gradually increases at higher number of cycles which is justified according to the mentioned reasons. 


\subsubsection{Electrochemical impedance spectroscopy (EIS)}

Investigation on the resistance components helps to study the limiting factors which affect the electrochemical reactions in the lithium-oxygen batteries. Fig. 7 presents the Nyquist diagrams of discharge and charge processes for the cathodes made using both $\mathrm{CNT}$ and $\mathrm{MnO}_{2}-\mathrm{CeO}_{2} / \mathrm{CNT}$ samples. As can be seen, the resistance components are increased as the discharge continues. In point (ii) (50\% depth of discharge), the resistance of $\mathrm{MnO}_{2}-\mathrm{CeO}_{2} / \mathrm{CNT}$ cathode is $20 \%$ increased which is due to lithium peroxide precipitation on the cathode. A 35\% increase is observed for the CNT sample. This difference corresponds to the existence of metal oxides on $\mathrm{CNT}$ in $\mathrm{MnO}_{2-}$ $\mathrm{CeO}_{2} / \mathrm{CNT}$ composite which results in homogeneous formation of precipitates and amorphous lithium peroxide as a good conductor of ions and electrons causing decrease of charge and discharge over potentials [41].

The highest resistance values are observed at point (iii) in which the battery has reached $100 \%$ DOD (depth of discharge). At point (iii), a Warburg is apparent in addition to a semicircle due to lithium peroxide and charge transfer resistance. This Warburg is because of limited diffusion of $\mathrm{O}_{2}$ and $\mathrm{Li}^{+}$resulted from closing the pores of cathode. A 55\% decrease in resistance occurs when using catalyst which may improve the discharge potential as well suggesting the resistance is decreased by modifying $\mathrm{MnO}_{2}$ with $\mathrm{CeO}_{2}$, probably because of the existence of lower valence state ion $\mathrm{Mn}^{3+}$, which may enhance the electron conductivity of the composite [42].

It can be seen in Fig. 7 that a decrease is observed at the charge process. In point (iv) which is the completely charged state, a decrease of about $95 \%$ is observed for the $\mathrm{MnO}_{2}-\mathrm{CeO}_{2} / \mathrm{CNT}$ cathode while it has reached to $\sim 30 \%$ of its initial value (point (i): before discharge) using the pristine CNT. Table 3 indicates resistance values for cathode samples at different discharge-charge status. The increase in resistance is attributed to the formation of lithium peroxide deposit and volume change. 
In CNT cathode, formation of irreversible oxides and also incomplete discharge process results in higher resistance compared to the cathode fabricated using $\mathrm{MnO}_{2}-\mathrm{CeO}_{2} / \mathrm{CNT}$ catalyst.

\subsubsection{Determining the charge-discharge products}

The charge-discharge products were determined using XRD analysis for the CNT and $\mathrm{MnO}_{2^{-}}$ $\mathrm{CeO}_{2} / \mathrm{CNT}$ cathode samples. Figs. $8 \mathrm{a}$ and $8 \mathrm{~b}$ exhibit the XRD patterns of discharged and charged cathodes, respectively, at $1^{\text {st }}, 5^{\text {th }}$ and $20^{\text {th }}$ cycles using $100 \mathrm{~mA} / \mathrm{g}$ current density. Also, the standard XRD patterns of lithium peroxide and lithium carbonate are given in Fig. 8c. The $\mathrm{Li}_{2} \mathrm{O}_{2} \mathrm{XRD}$ peaks in Fig. 8a are identified as the (100), (101), (102) and (110) peaks according to the standard XRD pattern of $\mathrm{Li}_{2} \mathrm{O}_{2}$ (JCPDS \#01-074-0115). Furthermore, the peaks corresponding to $\mathrm{Li}_{2} \mathrm{CO}_{3}$ (JCPDS \#01-087-0728) are also depicted in by red stars. Similar patterns have also been reported in literature for $\mathrm{Li}_{2} \mathrm{O}_{2}$ [43] and $\mathrm{Li}_{2} \mathrm{CO}_{3}$ [44]. Evidently, in pristine CNT cathode, the $\mathrm{Li}_{2} \mathrm{CO}_{3}$ is observed, in addition to lithium peroxide, which is due to carbon destruction by lithium peroxide and lithium superoxide. In $\mathrm{MnO}_{2}-\mathrm{CeO}_{2} / \mathrm{CNT}$ cathode, no peak is apparent at $1^{\text {st }}$ cycle. Also, no peak is visible at $5^{\text {th }}$ cycle indicating no lithium carbonate deposit exists. A small peak associated to $\mathrm{Li}_{2} \mathrm{CO}_{3}$ is observed at the $20^{\text {th }}$ cycle which shows that the $\mathrm{MnO}_{2}-\mathrm{CeO}_{2} / \mathrm{CNT}$ composite catalyst is stable at initial cycles but the CNT content of composite undergoes oxidation. It is clear in Fig. $8 \mathrm{~b}$ that both $\mathrm{Li}_{2} \mathrm{O}_{2}$ and $\mathrm{Li}_{2} \mathrm{CO}_{3}$ deposits are observable at $1^{\text {st }}$ and $5^{\text {th }}$ cycles of charge for the pristine CNT electrode. The existence of $\mathrm{Li}_{2} \mathrm{O}_{2}$ is related to the fact that the pristine CNT is not an appropriate catalyst for the OER thus it cannot convert the discharge products to oxygen and lithium ion. The XRD pattern displays no deposit at $1^{\text {st }}$ and $5^{\text {th }}$ cycles of charge for the nanocomposite electrode. The XRD pattern of the composite at $20^{\text {th }}$ cycle of charge reveals that the $\mathrm{Li}_{2} \mathrm{CO}_{3}$ deposits are mainly removed and their peaks are not visible in the XRD pattern. However, it is generally 
believed that the lithium-oxygen reaction is not reversible for repeated cycling in the current condition; hence it is not possible to determine the amount of side products only from the XRD patterns.

Comparing the cyclic performances of the $\mathrm{MnO}_{2}-\mathrm{CeO}_{2} / \mathrm{CNT}$ composite at $100 \mathrm{~mA} / \mathrm{g}$ and limited capacities of 500 and $1000 \mathrm{~mA} \cdot \mathrm{h} / \mathrm{g}_{\text {electrode }}$ in Figs. 5 and 6 exhibits that the charging potentials have no significant variations during initial cycles but they gradually increase at higher number of cycles. These results also justify that some low amounts of $\mathrm{Li}_{2} \mathrm{O}_{2}$ and $\mathrm{Li}_{2} \mathrm{CO}_{3}$ deposits exist at higher number of cycles resulting in higher charging potentials. Furthermore, the Nyquist plots in Fig. 7 are composed of a semicircle indicating the interface resistance and the chargetransfer resistance $\left(\mathrm{R}_{\mathrm{ct}}\right)$. It is evident that the intercepts of real impedances of both $\mathrm{CNT}$ and $\mathrm{MnO}_{2}$ $\mathrm{CeO}_{2} / \mathrm{CNT}$ composite at fully charged state are smaller than their corresponding intercepts of real impedances before discharge confirming the increase in the $\mathrm{R}_{\mathrm{ct}}$ and interface resistance after full charging which may be attributed to the existence of some amounts of side products (such as $\mathrm{Li}_{2} \mathrm{O}_{2}$ and $\left.\mathrm{Li}_{2} \mathrm{CO}_{3}\right)$.

\section{Conclusions}

$\mathrm{MnO}_{2}-\mathrm{CeO}_{2} / \mathrm{CNT}$ nanocomposite was synthesized through hydrothermal method in which the amounts of $\mathrm{C}, \mathrm{MnO}_{2}$, and $\mathrm{CeO}_{2}$ components were 55, 20, and 25\%, respectively. The surface area for this composite was $93 \mathrm{~m}^{2} / \mathrm{g}$ which was $10 \%$ lower compared to that of the pristine CNT. The heat treatment procedure resulted in improvement of the cathode battery performance. The performances of fabricated cathodes using nanocomposite were evaluated at different current current densities and different cycles. The discharge capacity of $7980 \mathrm{~mA} . \mathrm{h} / \mathrm{g}_{\text {electrode }}$ was obtained at $50 \mathrm{~mA} / \mathrm{g}$ current density while it was $6860 \mathrm{~mA} . \mathrm{h} / \mathrm{g}_{\text {electrode }}$ at $100 \mathrm{~mA} / \mathrm{g}$. The charging over-voltage 
of the synthesized catalyst was equal to $0.68 \mathrm{~V}$ at $100 \mathrm{~mA} / \mathrm{g}$ which was $0.73 \mathrm{~V}$ lower than that of the pristine CNT cathode sample. The cycleability experiments verified that the $\mathrm{MnO}_{2}-\mathrm{CeO}_{2} / \mathrm{CNT}$ cathodic material had an appropriate cyclic performance during 70 cycles.

\section{Acknowledgments}

The financial supports of this work by the Iran National Science Foundation (INSF, grant number: 93030123), Tehran, Iran and the Research Office of Amirkabir University of Technology (Tehran Polytechnic), Tehran, Iran are gratefully acknowledged.

\section{References}

[1] M. Winter, R. J. Brodd, Chemical Reviews 104 (2004) 4245-4270.

[2] B. Dunn, H. Kamath, J. M. Tarascon, Science 334 (2011) 928-935.

[3] Z. Yang, J. Zhang, M. C. Kintner-Meyer, X. Lu, D. Choi, J. P. Lemmon, J. Liu, Chemical Reviews 111 (2011) 3577-3613.

[4] N. Feng, P. He, H. Zhou, ChemSusChem 8 (2015) 600-602.

[5] W.-J. Kwak, K. C. Lau, C.-D. Shin, K. Amine, L. A. Curtiss, Y.-K. Sun, ACS Nano 9 (2015) $4129-4137$.

[6] Y. Hu, T. Zhang, F. Cheng, Q. Zhao, X. Han, J. Chen, Angewandte Chemie International Edition English 54 (2015) 4338-4343.

[7] L. Johnson, C. Li, Z. Liu, Y. Chen, S. A. Freunberger, P. C. Ashok, B. B. Praveen, K. Dholakia, J.-M. M. Tarascon, P. G. Bruce, Nature Chemistry 6 (2014) 1091-1099.

[8] J. Wang, Y. Li and X. Sun, Nano Energy 2 (2013) 443-467. 
[9] X. Ren, S. S. Zhang, D. T. Tran, J. Read, Journal of Materials Chemistry 21 (2011) 1011810125.

[10] A. De’bart, J. Bao, G. Armstrong, P. G. Bruce, Journal of Power Sources 174 (2007) 11771182.

[11] G. Girishkumar, B. McCloskey, A.C. Luntz, S. Swanson, W. Wilcke, Journal of Physical Chemistry Letters 1 (2010) 2193-2203.

[12] M.M.O. Thotiyl, S.A. Freunberger, P.G. Bruce, Journal of the American Chemical Society 135 (2013) 494-500.

[13] A. Débart, A. J. Paterson, J. Bao, P. G. Bruce, Angewandte Chemie International Edition 47 (2008) 4521-4524.

[14] Y.-C. Lu, H. A. Gasteiger, M. C. Parent, V. Chiloyan, Y. Shao-Horn, Electrochemical and Solid State Letters 13 (2010) A69-A72.

[15] Y.-C. Lu, Z. Xu, H. A. Gasteiger, S. Chen, K. H. Schifferli, Y. Shao-Horn, Journal of the American Chemical Society 132 (2010) 12170-12171.

[16] H. Cheng, K. Scott, Journal of Power Sources 195 (2010) 1370-1374.

[17] M. Salehi, Z. Shariatinia, Electrochimica Acta 188 (2016) 428-440.

[18] G. Zhao, J. Lv, Z. Xu, L. Zhang, K. Sun, Journal of Power Sources 248 (2014) 1270-1274.

[19] G. Zhang, J. Zheng, R. Liang, C. Zhang, B. Wang, M. Au, M. Hendrickson, E. Plichta, Journal of Electrochemical Society 158 (2011) A822-A827.

[20] D. Kundu, R. Black, E.J. Berg, L.F. Nazar, Energy \& Environmental Science 8 (2015) 12921298.

[21] R. Black, J.H. Lee, B. Adams, C.A. Mims, L.F. Nazar, Angewandte Chemie 125 (2013) 410414. 
[22] J.J. Xu, D. Xu, Z.L. Wang, H.G. Wang, L.L. Zhang, X.B. Zhang, Angewandte Chemie International Edition 52 (2013) 3887-3890.

[23] Z.L. Wang, D. Xu, J.J. Xu, L.L. Zhang, X.B. Zhang, Advanced Functional Materials 22 (2012) 3699-3705.

[24] J. Shui, F. Du, C. Xue, Q. Li, L. Dai, ACS Nano 8 (2014) 3015-3022.

[25] L. Wang, X. Zhao, Y. Lu, M. Xu, D. Zhang, R. S. Ruoff, K. J. Stevenson, J. B. Goodenough, Journal of Electrochemical Society 158 (2011) A1379-A1382.

[26] Z. Ma, X. Yuan, L. Li, Zi-F. Ma, D. P. Wilkinson, L. Zhang, J. Zhang, Energy \& Environmental Science 8 (2015) 2144-2198.

[27] F. Qiu, P. He, J. Jiang, X. Zhang, S. Tong, H. Zhou, Chemical Communications 52 (2016) 2713-2716.

[28] C. Shu, Y. Lin, D. Su, Journal of Materials Chemistry A 4 (2016) 2128-2136.

[29] Z. Jian, P. Liu, F. Li, P. He, X. Guo, M. Chen, H. Zhou, Angewandte Chemie International Edition 53 (2014) 442-446.

[30] R. Gao, J. Zhu, X. Xiao, Z. Hu, J. Liu, X. Liu, Journal of Physical Chemistry C 119 (2015) 4516-4523.

[31] Y. Shen, D. Sun, L. Yu, W. Zhang, Y. Shang, H. Tang, J. Wu, A. Cao, Y. Huang, Carbon 62 (2013) 288-295.

[32] Y. Chen, B. Jacob, C. Jin, F.L. Chen, Journal of Power Sources 204 (2012) 40-45.

[33] Y. Zhu, S. Liu, C. Jin, S. Bie, R. Yang, J. Wu, Journal of Materials Chemistry A 3 (2015) $13563-13567$.

[34] Y. Liu, M. Wang, L.-J. Cao, M.-Y. Yang, S. Ho-S. Cheng, C.-W. Cao, K.-L. Leung, C.-Y. Chung, Z.-G. Lu, Journal of Power Sources 286 (2015) 136-144. 
[35] W.M. Dose, S.W. Donne, Journal of Power Sources 247 (2014) 852-857.

[36] J.A. Lee, C.E. Newnham, F.L. Tye, Journal of Colloid and Interface Science 42 (1973) $372-380$.

[37] J.A. Lee, C.E. Newnham, F.S. Stone, F.L. Tye, Journal of Colloid and Interface Science 45 (1973) 289-294.

[38] W.M. Dose, S.W. Donne, Journal of Thermal Analysis and Calorimetry (2011) 105:113-122.

[39] W.M. Dose, S.W. Donne, Electrochimica Acta 105 (2013) 305-313.

[40] Y. Jiang, J. Cheng, L. Zou, X. Li, Y. Gong, B. Chi, J. Pu, J. Li, Electrochimica Acta 210 (2016) 712-719.

[41] E. Yilmaz, C. Yogi, K. Yamanaka, T. Ohta, H. R. Byon, Nano Letters 13 (2013) 4679-4684.

[42] W.X. Ji, R. Shen, R. Yang, G.Y. Yu, X.F. Guo, L.M. Peng, W.P. Ding, Journal of Materials Chemistry A 2 (2014) 699-704.

[43] P. Tan, W. Shyy, T. S. Zhao, Z. H. Wei, L. An, Journal of Power Sources 278 (2015) 133-140.

[44] Y. Lu, Y. Liu, C. Zhou, G. Luo, Industrial \& Engineering Chemistry Research 53 (2014) 11015-11020. 


\begin{tabular}{|c|c|c|}
\hline Cathode & Specific surface area $\left(\mathrm{m}^{2} / \mathrm{g}\right)$ & Average pore volume $\left(\mathrm{cm}^{3} / \mathrm{g}\right)$ \\
\hline CNT pristine & 103 & 0.21 \\
\hline CNT-MnO ${ }_{2}$ optimized & 80 & 0.15 \\
\hline $\mathrm{MnO}_{2}-\mathrm{CeO}_{2} / \mathrm{CNT}$ & 93 & 0.17 \\
\hline
\end{tabular}

The specific surface areas obtained from Brunauer-Emmett-Teller (BET) isotherms and the average pore volumes of three cathodic materials. 


\section{Table 2}

The discharge capacities and potentials at different current densities.

\begin{tabular}{lccccccc}
\hline Current density (mA/gelectrode $)$ & 50 & 100 & 200 & 500 & 1000 & 2000 & 3000 \\
\hline Discharge capacity (mA.h/gelectrode $)$ & 7980 & 6860 & 6100 & 5890 & 5400 & 4000 & 3350 \\
Discharge voltage plateau (V) & 2.76 & 2.76 & 2.67 & 2.62 & 2.59 & 2.53 & 2.41 \\
\hline
\end{tabular}




\section{Table 3}

The resistance values (ohm) for cathode samples at different discharge status. ${ }^{\text {a }}$

\begin{tabular}{lccccc}
\hline Cathode & R solution & Point (i) & Point (ii) & Point (iii) & Point (iv) \\
\hline Pristine CNT & 5 & 50 & 68 & 113 & 71.5 \\
$\mathrm{MnO}_{2}-\mathrm{CeO}_{2} / \mathrm{CNT}$ & 5 & 48 & 58 & 73 & 50.5 \\
\hline
\end{tabular}

${ }^{\mathrm{a}}$ Point (i): before discharge, point (ii): 50\% discharge depth, point (iii): $100 \%$ discharge depth, point (iv): fully charged. 


\section{Figures captions}

Fig. 1. (a) The SEM image of star-like structure of $\mathrm{MnO}_{2}-\mathrm{CeO}_{2} / \mathrm{CNT}$ nanocomposite. (b) The EDX spectrum of the synthesized nanocomposite. (c) The mapping images of $\mathrm{MnO}_{2}-\mathrm{CeO}_{2} / \mathrm{CNT}$.

Fig. 2. (a) The charge-discharge diagrams of cathode samples fabricated with and without heat treatment. (b) The Nyquist diagrams for cathodes fabricated with and without heat treatment after discharge.

Fig. 3. (a) The charge and discharge diagrams of pristine $\mathrm{CNT}, \mathrm{CNT} / \mathrm{MnO}_{2}$ and $\mathrm{MnO}_{2}-\mathrm{CeO}_{2} / \mathrm{CNT}$ composite with over-voltages (current density $=100 \mathrm{~mA} / \mathrm{g}_{\text {electrode }}$ ). (b) The discharge capacity and over-voltage of charge and discharge for the three studied samples (current density $=100$ $\left.\mathrm{mA} / \mathrm{g}_{\text {electrode }}\right)$.

Fig. 4. The discharge diagrams of lithium-oxygen batteries using $\mathrm{MnO}_{2}-\mathrm{CeO}_{2} / \mathrm{CNT}$ at current densities of 50 to $3000 \mathrm{~mA} / \mathrm{g}_{\text {electrode }}$.

Fig. 5. (a) The cyclic performance of $\mathrm{MnO}_{2}-\mathrm{CeO}_{2} / \mathrm{CNT}$ composite at $500 \mathrm{~mA} / \mathrm{g}$ and limited capacity of $1000 \mathrm{~mA} \cdot \mathrm{h} / \mathrm{g}_{\text {electrode }}$ (b) The variation of oxygen reduction and evolutionat in the reaction halfway.

Fig. 6. (a) The cyclic performance of $\mathrm{MnO}_{2}-\mathrm{CeO}_{2} / \mathrm{CNT}$ composite at $100 \mathrm{~mA} / \mathrm{g}$ and limited capacity of $500 \mathrm{~mA} \cdot \mathrm{h} / \mathrm{g}_{\text {electrode }}$ (b) The potential variations of oxygen reduction and evolution in the reaction halfway.

Fig. 7. The Nyquist diagrams for different times of charge and discharge for the cathodes made using $\mathrm{CNT}$ and $\mathrm{MnO}_{2}-\mathrm{CeO}_{2} / \mathrm{CNT}$ samples. (i): before discharge, (ii): $50 \%$ discharge depth, (iii): $100 \%$ discharge depth, (iv): fully charged.

Fig. 8. The XRD patterns of (a) discharged and (b) charged cathodes at $100 \mathrm{~mA} / \mathrm{g}$ at different cycles. (i) Pristine CNT after $1^{\text {st }}$ cycle, (ii) Pristine $\mathrm{CNT}$ after $5^{\text {st }}$ cycle, (iii) $\mathrm{MnO}_{2}-\mathrm{CeO}_{2} / \mathrm{CNT}$ after $1^{\text {st }}$ cycle, (iv) $\mathrm{MnO}_{2}-\mathrm{CeO}_{2} / \mathrm{CNT}$ after $5^{\text {st }}$ cycle, (v) $\mathrm{MnO}_{2}-\mathrm{CeO}_{2} / \mathrm{CNT}$ after $20^{\text {st }}$ cycle. (c) The standard XRD patterns of $\mathrm{Li}_{2} \mathrm{O}_{2}$ and $\mathrm{Li}_{2} \mathrm{O}_{3}$. 


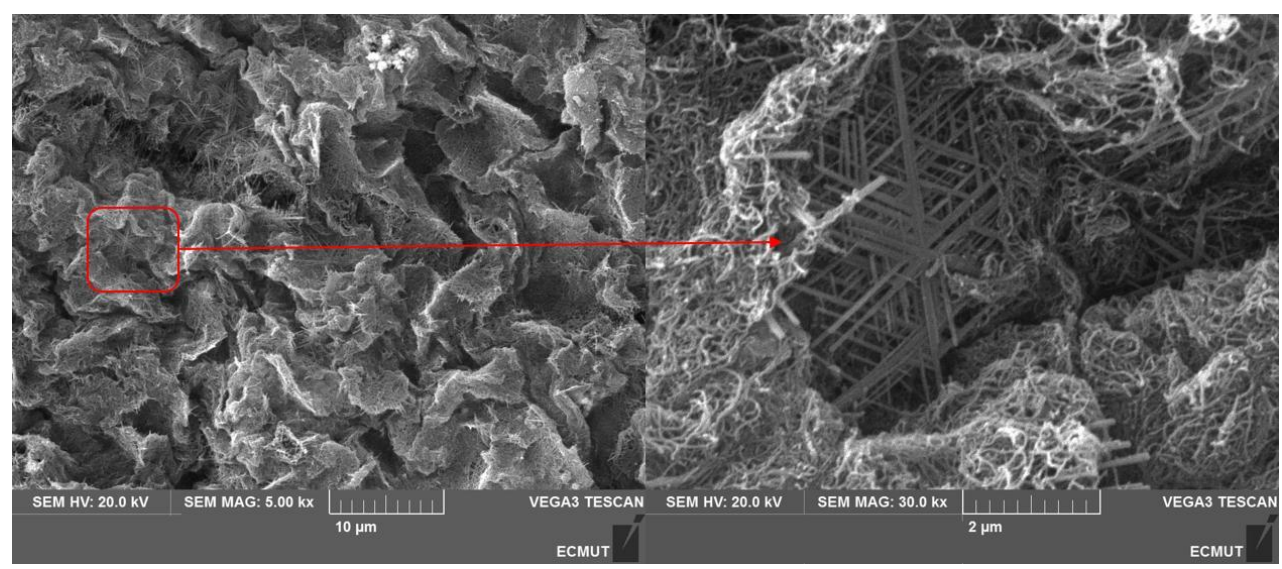

(a)

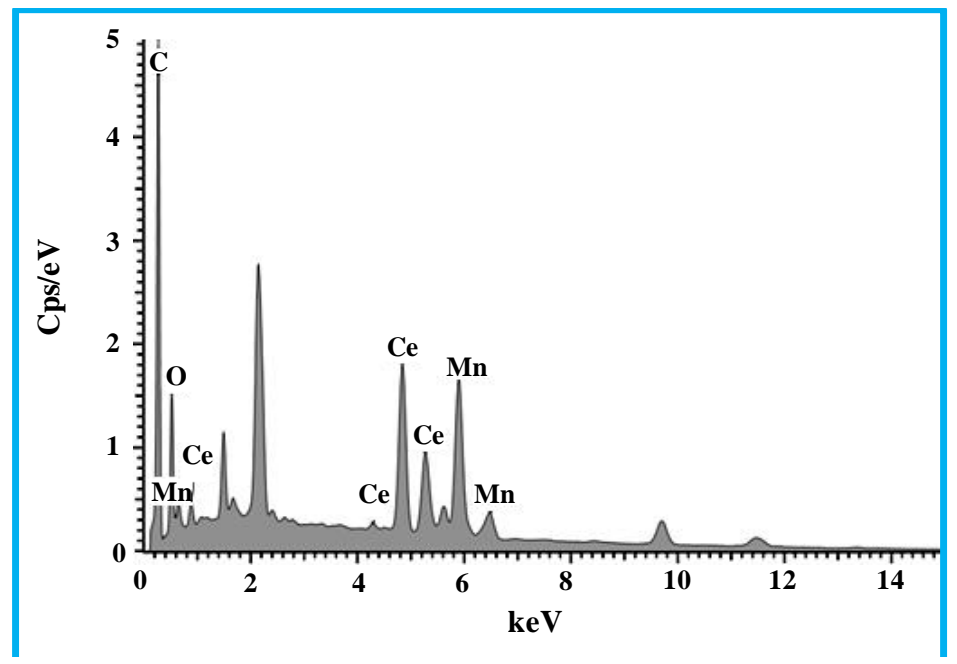

(b)

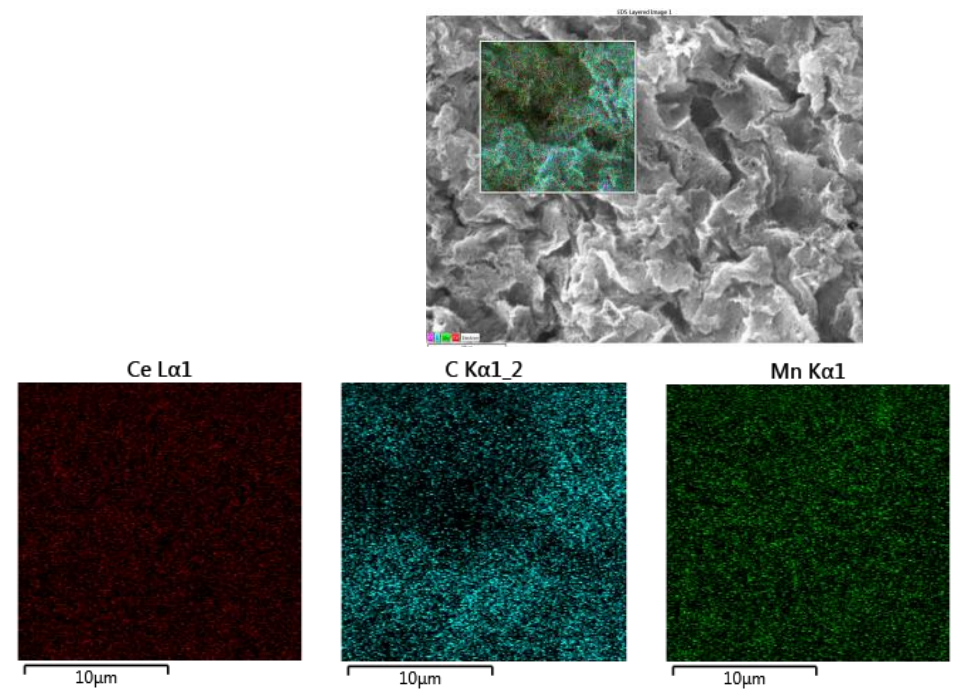

(c)

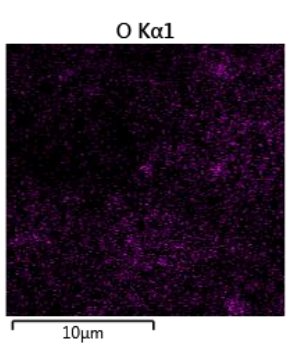

Fig. 1. (a) The SEM image of star-like structure of $\mathrm{MnO}_{2}-\mathrm{CeO}_{2} / \mathrm{CNT}$ nanocomposite. (b) The EDX spectrum of the synthesized nanocomposite. (c) The mapping images of $\mathrm{MnO}_{2}-\mathrm{CeO}_{2} / \mathrm{CNT}$. 
Fig. 2. (a) The charge-discharge diagrams of cathode samples fabricated with and without heat treatment.

(b) The Nyquist diagrams for cathodes fabricated with and without heat treatment after discharge. 
Fig. 3. (a) The charge and discharge diagrams of pristine $\mathrm{CNT}, \mathrm{CNT} / \mathrm{MnO}_{2}$ and $\mathrm{MnO}_{2}-\mathrm{CeO}_{2} / \mathrm{CNT}$ composite with over-voltages (current density $=100 \mathrm{~mA} / \mathrm{g}_{\text {electrode }}$ ). (b) The discharge capacity and over-voltage of charge and discharge for the three studied samples (current density $=100 \mathrm{~mA} / \mathrm{g}_{\text {electrode }}$ ). 


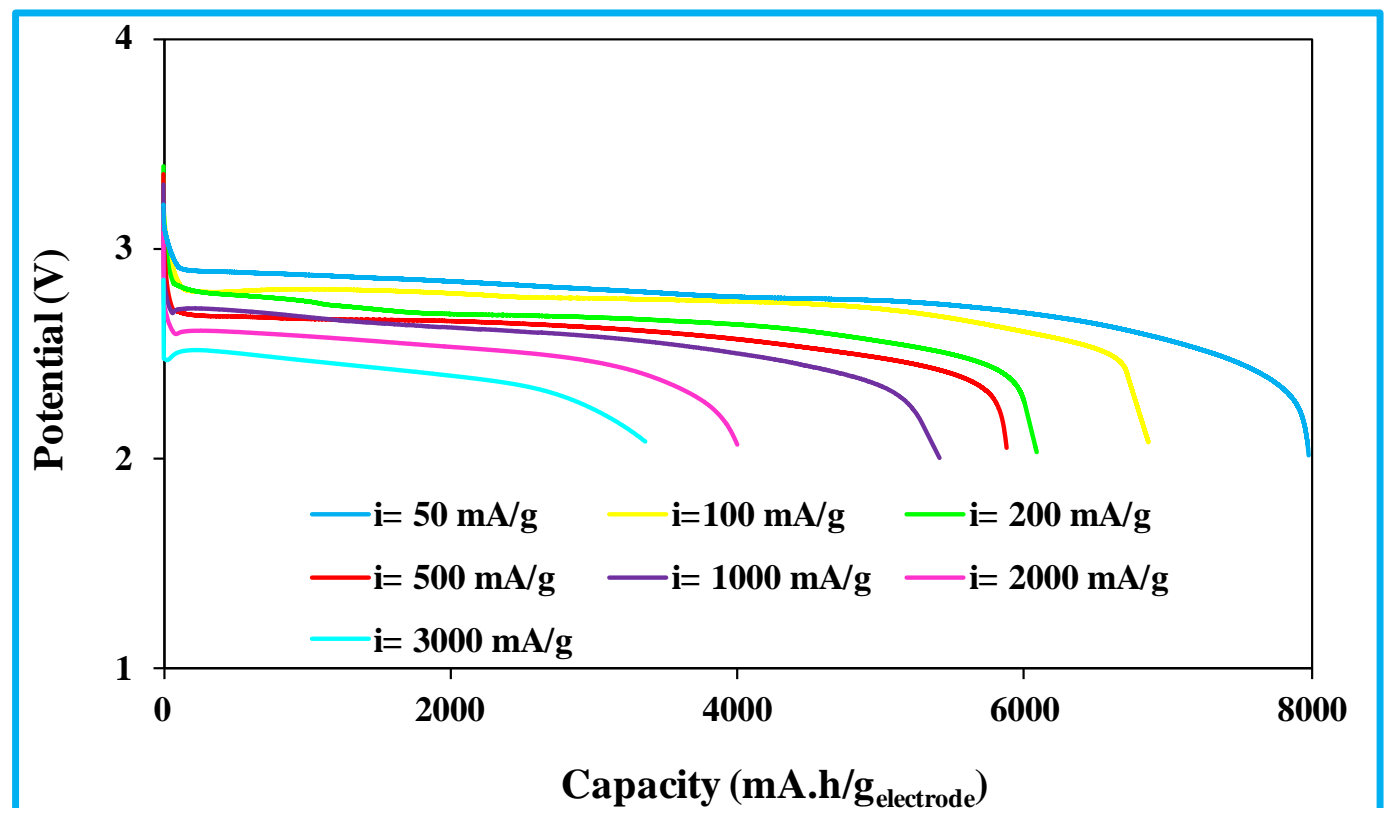

Fig. 4. The discharge diagrams of lithium-oxygen batteries using $\mathrm{MnO}_{2}-\mathrm{CeO}_{2} / \mathrm{CNT}$ at current densities of 50 to $3000 \mathrm{~mA} / \mathrm{g}_{\text {electrode }}$. 


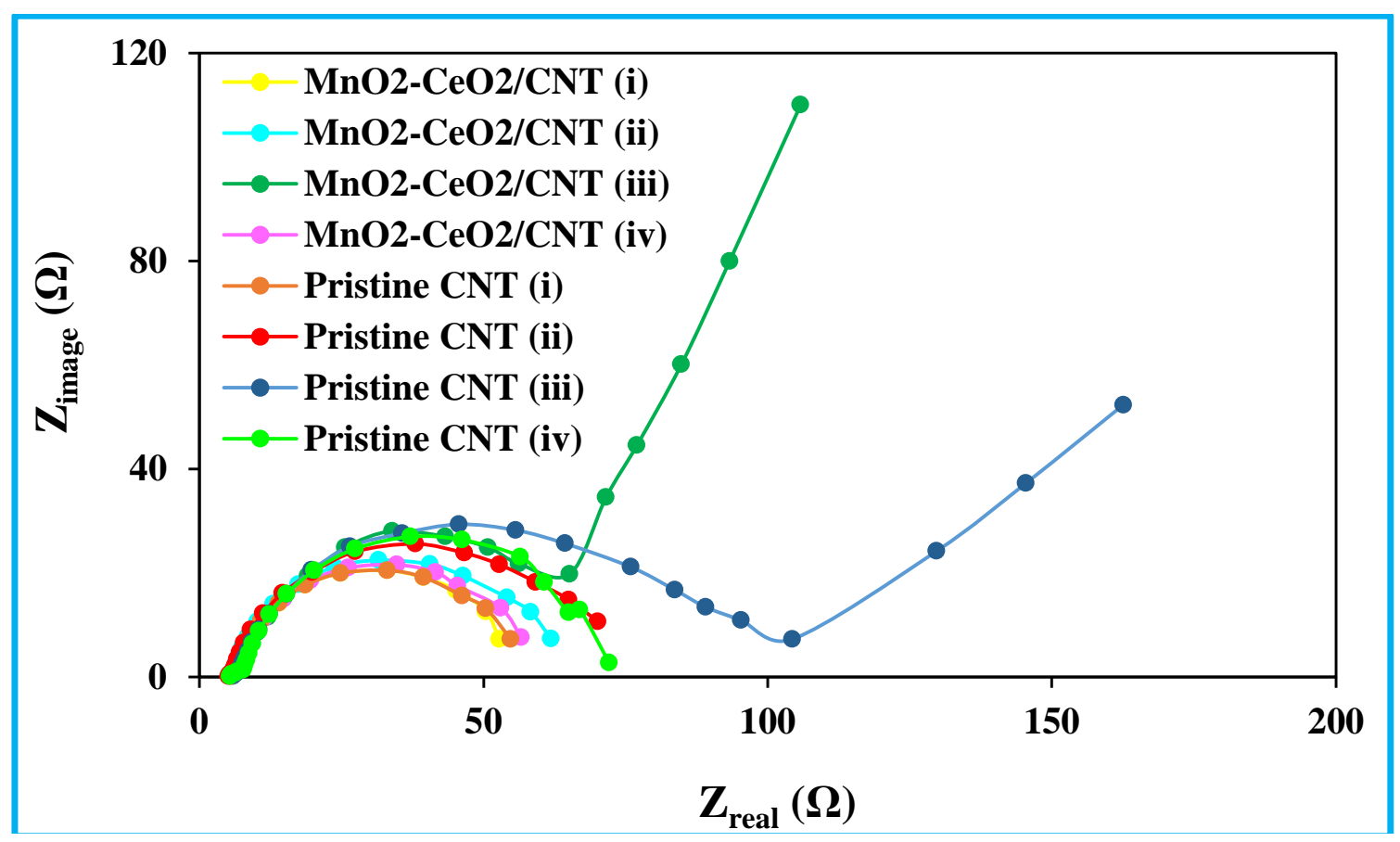

Fig. 7. The Nyquist diagrams for different times of charge and discharge for the cathodes made using $\mathrm{CNT}$ and $\mathrm{MnO}_{2}-\mathrm{CeO}_{2} / \mathrm{CNT}$ samples.

(i): before discharge, (ii): $50 \%$ discharge depth, (iii): 100\% discharge depth, (iv): fully charged. 


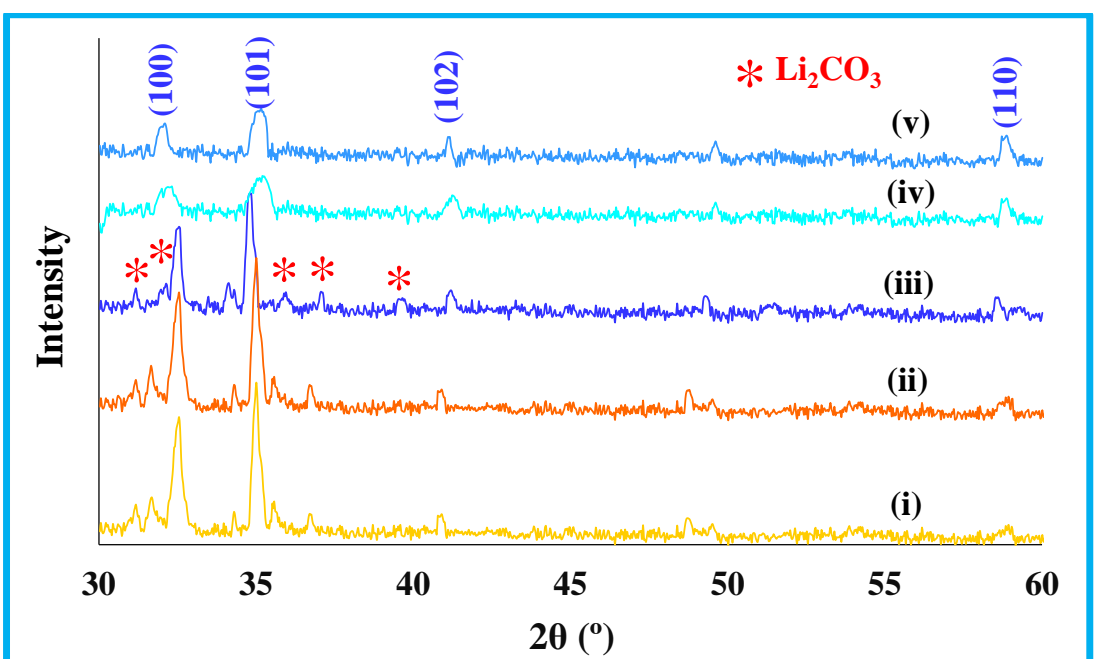

(a)

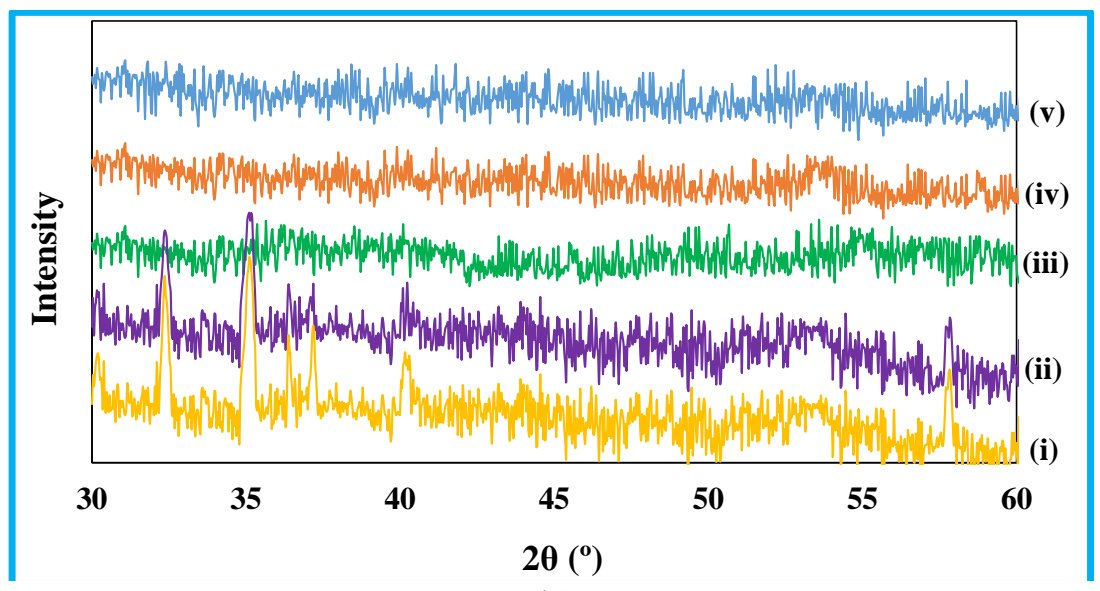

(b)
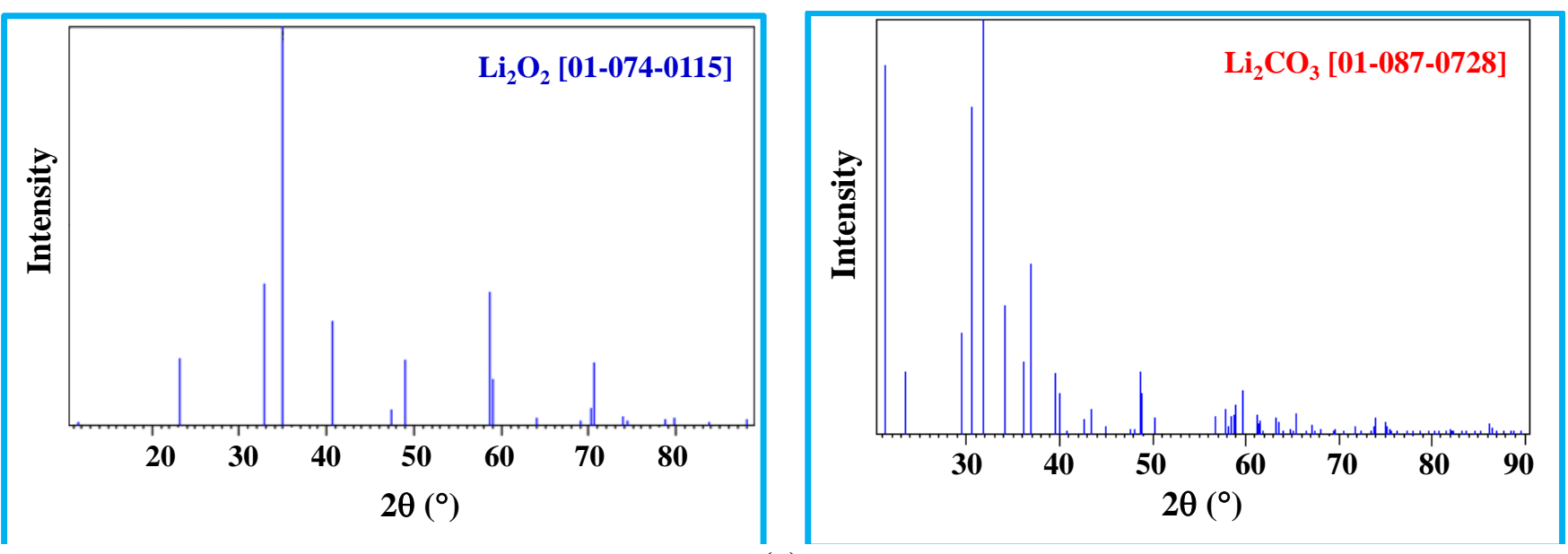

(c)

Fig. 8. The XRD patterns of (a) discharged (b) and charged cathodes at $100 \mathrm{~mA} / \mathrm{g}$ at different cycles. (i) Pristine CNT after $1^{\text {st }}$ cycle, (ii) Pristine CNT after $5^{\text {st }}$ cycle, (iii) $\mathrm{MnO}_{2}-\mathrm{CeO}_{2} / \mathrm{CNT}$ after $1^{\text {st }}$ cycle, (iv) $\mathrm{MnO}_{2}-\mathrm{CeO}_{2} / \mathrm{CNT}$ after $5^{\text {st }}$ cycle, (v) $\mathrm{MnO}_{2}-\mathrm{CeO}_{2} / \mathrm{CNT}$ after $20^{\text {st }}$ cycle. (c) The standard XRD patterns of $\mathrm{Li}_{2} \mathrm{O}_{2}$ and $\mathrm{Li}_{2} \mathrm{CO}_{3}$. 

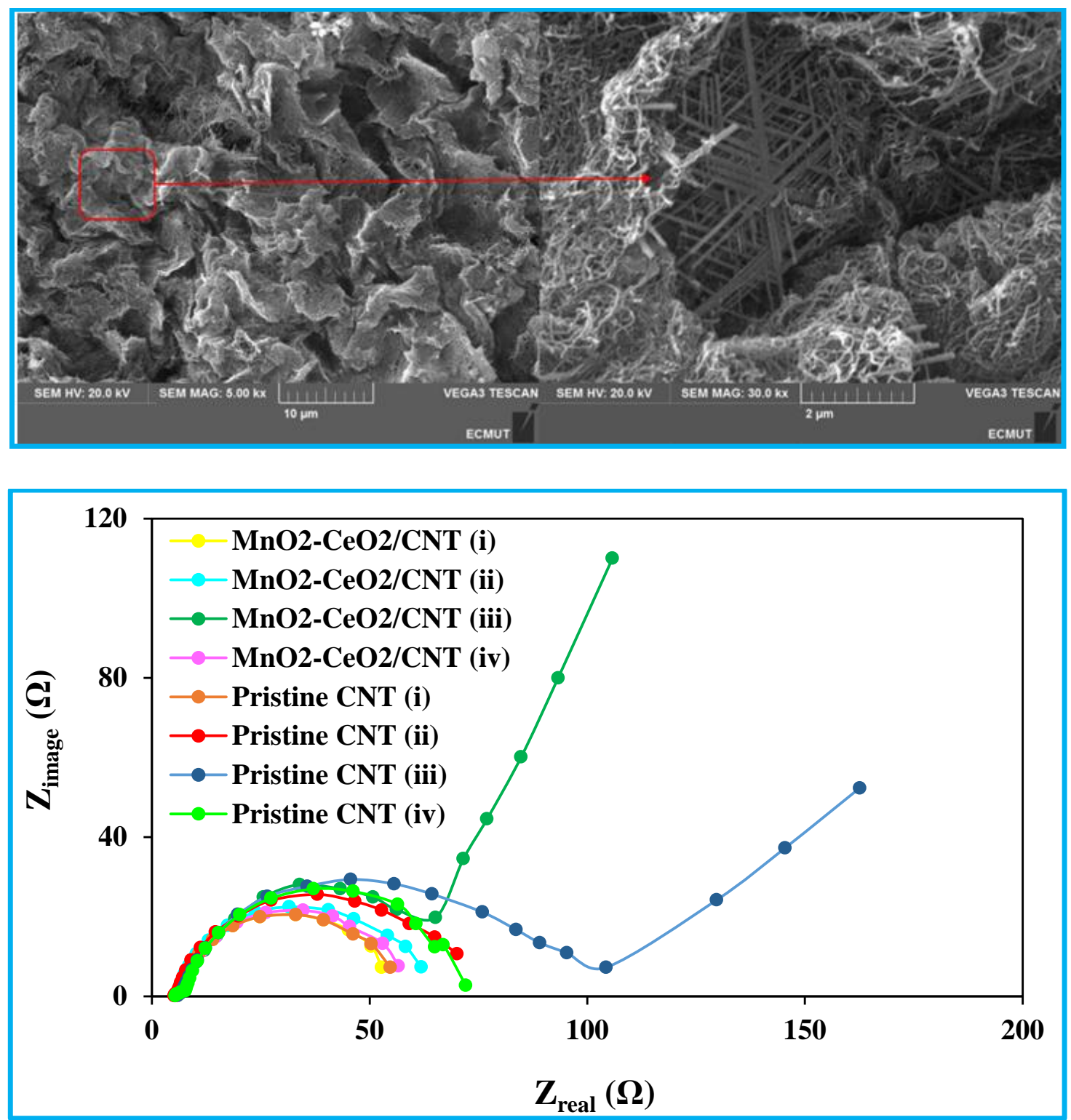